\title{
EKSTRAKSI DAN PENENTUAN GUGUS FUNGSI ASAM HUMAT DARI PUPUK KOTORAN SAPI
}

\author{
Nurlina $^{1 *}$, Intan Syahbanu ${ }^{1}$, Mirna Tersiana Tamnasi ${ }^{1}$, \\ Chyntia Nabela ${ }^{1}$, Maria Desi Furnata ${ }^{1}$
}

1 Jurusan Kimia, Fakultas MIPA, Universitas Tanjungpura, Kalimantan Barat, Indonesia

*Corresponding author: nurlina@chemistry.untan.ac.id

ARTICLE INFO
Article history:
Received 21 May
2018
Accepted 28 May
2018
Available online
26 June 2018
Keywords:
Extraction
Humic acid
Cow manure
Fertilizer
Total acidity

\section{ABSTRACT}

Cow manure fertilizer was used as raw material for the extraction of humic acid in this research. The aim of this research were extraction of humic acid from cow manure fertilizer, characterization of functional groups based on FTIR spectra, and determination of humic acid functional groups. Humic acid extraction from cow manure used $0.050 \mathrm{M} ; 0.100 \mathrm{M} ; 0.250 \mathrm{M}$ dan $0.500 \mathrm{M} \mathrm{KOH}$ solution. A cow manure fertilizer were shaken with $\mathrm{KOH}$ solution for $1 ; 2 ; 4$ and $6 \mathrm{~h}$. The quantitative determination of oxygen-containing functional groups of humic acid was conducted by titrimetri. The FTIR spectrum showed the presence of $-\mathrm{OH}$ group and N-H stretching (bands $3361.46 \mathrm{~cm}^{-1}$ ); C-H aliphatic for $\mathrm{CH}_{2}, \mathrm{CH}_{3} \quad\left(2946.52 \mathrm{~cm}^{-1}\right.$ and $\left.1442.24 \mathrm{~cm}^{-1}\right) ; \mathrm{C}=\mathrm{C}$ aromatic components $\left(1626.48 \mathrm{~cm}^{-1}\right)$; COO- symmetric stretching (1521.71 $\left.\mathrm{cm}^{-1}\right)$; C-O stretching from $-\mathrm{COOH}\left(1229.74 \mathrm{~cm}^{-1}\right)$. Total acidity value was $500 \mathrm{cmole.kg}^{-1}$ (Baryta Absorption Method); carboxyl

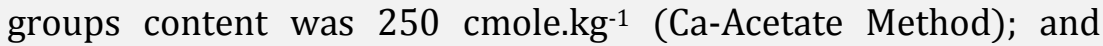
phenol $(\mathrm{OH})$ concentration was $250 \mathrm{cmole}^{-\mathrm{kg}^{-1}}$. It can be concluded that humic acid successfully extracted from cow manure fertilizer using $0.250 \mathrm{KOH}$ solution as extractant for $2 \mathrm{~h}$, which has yield of $4.486 \%$ humic acid.

(C) 2018 IJoPAC. All rights reserved

\section{Pendahuluan}

Asam humat merupakan salah satu fraksi dari senyawa humat yang termasuk dalam bahan organik tanah (natural organic matter). Senyawa ini berasal dari degradasi biologis (enzimatis), kimia maupun abiotik dari material organik yang ada di atas tanah [1]. Asam humat larut pada $\mathrm{pH}$ tinggi (keadaan basa) namun tidak larut pada pH rendah (keadaan asam).

Berbagai publikasi penelitian telah membuktikan bahwa asam humat bertanggungjawab dalam peningkatan produksi dan kualitas tanaman pangan, misalnya padi, gandum, dan brokoli [2], [3], [4], [5]. Asam humat terbukti mampu memberikan perbaikan secara biologis dan fisiologi tanaman [6], [7]. Asam humat berperan dalam memaksimalkan fungsi akar sehingga tanaman dapat menyerap unsur hara yang lebih banyak [8]. Pengaplikasian asam humat pada tanah berperan dalam meningkatkan penyerapan fosfor $(\mathrm{P})$, kalium $(\mathrm{K})$, magnesium $(\mathrm{Mg})$, natrium $(\mathrm{Na})$, tembaga $(\mathrm{Cu})$ dan seng $(\mathrm{Zn})^{[9]}$.

Asam humat dapat diisolasi dari tanah gambut, namun peran ekosistem gambut yang dapat mempertahankan hidrologi dan cadangan karbon untuk lingkungan hidup menyebabkan kepentingan melindungi ekosistem gambut lebih penting sehingga fungsinya dapat 
dipertahankan dimasa yang akan datang. Eksplorasi asam humat dapat dilakukan dengan mencari sumber daya alam lainnya yang dapat dijadikan sumber asam humat.

Pupuk kotoran sapi merupakan sumber bahan organik yang dimungkinkan mengandung asam humat, karena pupuk kotoran sapi telah melalui proses biodegradasi melalui pengomposan yang merupakan model sederhana proses humifikasi bahan organik. Pada umumnya, asam humat terbentuk dari proses dekomposisi bahan organik dengan jangka waktu yang cukup lama yang dibantu oleh mikroorganisme pengurai Hal ini serupa dengan teknik pengomposan, karena teknik pengomposan merupakan salah satu cara dekomposisi bahan organik dengan jangka waktu yang bisa diatur, yang mengakibatkan rasio $\mathrm{C} / \mathrm{N}$ bahan organik menjadi turun (terdegradasi). Ekstraksi asam humat dari serbuk kotoran sapi telah dilakukan menggunakan larutan $\mathrm{NaOH}$ 0,1 M [10]. Asam humat yang diekstraksi dari kotoran ternak berperan sebagai auxin-like compounds untuk meningkatkan aktivitas enzimatik pada akar tanaman barley [11].

Penelitian ini akan mengekstrak asam humat dari pupuk kotoran sapi. Pupuk kotoran sapi adalah kotoran sapi yang telah dikomposkan secara sedehana kemudian dijadikan pupuk. Ekstraksi dilakukan dengan variasi konsentrasi larutan KOH yang divariasi konsentrasinya (0,050-0,500 M) dan variasi waktu pengocokan (1-6 jam). Asam humat yang diperoleh dikarakterisasi serapan gugus fungsinya dengan FTIR dan ditentukan kandungan total keasaman, kandungan gugus karboksilat dan kandungan gugus - $\mathrm{OH}$ fenolatnya.

\section{Material dan Metode}

\subsection{Pengumpulan sampel}

Pupuk kotoran sapi diperoleh dari salah satu tempat peternakan sapi di Kota Pontianak. Pupuk yang diperoleh sudah dalam keadaan kering.

\subsection{Ekstraksi Asam Humat}

Secara umum, metode ekstraksi asam humat dilakukan dengan merujuk pada metode dari Stevenson [12]. Variasi parameter yang digunakan untuk mengekstraksi asam humat yang digunakan dalam penelitian ini adalah konsentrasi larutan basa pengekstrak dan lama waktu pengocokan pupuk kotoran sapi dengan larutan basa pengekstrak. Larutan basa pengekstrak yang digunakan adalah $\mathrm{KOH}$ dengan variasi konsentrasi 0,050 M; 0,100 M; 0,250 M dan 0,50 M. Waktu pengocokan pupuk kotoran sapi dengan larutan $\mathrm{KOH}$ divariasi dari 1 jam sampai dengan 6 jam.

Pupuk kotoran sapi yang telah dibersihkan, dikeringkan dan dihaluskan, dimasukkan ke dalam erlenmeyer yang berisi larutan basa pengekstrak dengan rasio 1:12,5. Campuran dikocok menggunakan shaker. Campuran tersebut didiamkan 24 jam. Setelah 24 jam, campuran disaring untuk memperoleh filtrat dan endapan. Filtrat hasil saringan ditambahkan $\mathrm{HCl}$ pekat hingga $\mathrm{pH}$ 1, dikocok menggunakan shaker, kemudian didiamkan selama 24 jam. Campuran disaring hingga diperoleh filtrat dan endapan. Proses pemisahan dengan $\mathrm{KOH}$ dan $\mathrm{HCl}$ ini diulang dua kali. Endapan yang diperoleh dicuci berulang kali dengan akuades hingga air pencucian bebas ion $\mathrm{Cl}^{-}$, yang dapat dibuktikan dengan tidak adanya pembentukan endapan putih $\mathrm{AgNO}_{3}$ ketika air pencucian direaksikan dengan larutan $\mathrm{AgCl}$. Setelah dicuci asam humat tersebut dikeringkan pada suhu $60^{\circ} \mathrm{C}$. Asam humat yang diperoleh dikarakterisasi dengan FTIR.

\subsection{Penentuan Total Keasaman}

Total keasaman asam humat hasil ektraksi dari pupuk kompos kotoran sapi dihitung dengan metode barium hidroksida (Baryta Absorption Methods). Sebanyak $20 \mathrm{mg}$ asam humat ditambahkan dengan $10 \mathrm{ml} \mathrm{Ba(OH})_{2}$ 0,2 M. Campuran ini dikocok selama 24 jam pada temperatur ruangan. Hasil dari pengocokan adalah terbentuknya filtrat dan endapan. Endapan dicuci dengan akuades. Larutan dititrasi dengan $\mathrm{HCl}$ 0,25M hingga $\mathrm{pH}$ 8,4. Titrasi dilakukan 
secara triplo. Prosedur tersebut juga dilakukan untuk blanko yaitu 10 mL larutan $\left.\mathrm{Ba}(\mathrm{OH})_{2}\right)$ 0,2 $\mathrm{N}[12]$. Total keasaman dihitung dengan persamaan sebagai berikut:

$$
\text { Total keasaman }\left(\mathrm{cmol} \mathrm{kg}^{-1}\right)=\frac{\left(V_{\text {blanko }}-V_{\text {sampel }}\right) \times N_{\text {basa }} \times 10^{5}}{V_{\text {sampl }}(\mathrm{mg})}
$$

\subsection{Penentuan Kandungan Gugus Karboksilat}

Penentuan kandungan gugus karboksilat dari pupuk kompos kotoran sapi dilakukan dengan metode Ca-asetat. Sebanyak $20 \mathrm{mg}$ asam humat ditempatkan ke dalam erlenmeyer dan ditambahkan $10 \mathrm{ml} \mathrm{Ca}\left(\mathrm{CH}_{3} \mathrm{COO}\right)_{2}$ 0,1 $\mathrm{N}$ dan $40 \mathrm{ml}$ akuades. Campuran ini dikocok selama 24 jam pada temperatur ruangan. Hasil dari pengocokan adalah terbentuknya filtrat dan endapan Endapan dicuci dengan akuades. Larutan dititrasi dengan larutan standar $\mathrm{NaOH} \mathrm{0,1} \mathrm{M} \mathrm{hingga} \mathrm{pH}$ 9,8. Titrasi dilakukan secara triplo. Prosedur diulangi untuk blanko yaitu campuran $10 \mathrm{ml}$ $\mathrm{Ca}\left(\mathrm{CH}_{3} \mathrm{COO}\right)_{2}$ 0,1 $\mathrm{N}$ dan $40 \mathrm{ml}$ akuades [12]. Kandungan gugus karboksilat dihitung dengan persamaan sebagai beikut:

$$
\text { Kandungan gugus karboksilat }\left(\mathrm{cmol} \mathrm{kg}^{-1}\right)=\frac{\left(\mathrm{V}_{\text {sampel }}-\mathrm{V}_{\text {blanko }}\right) \times \mathrm{N}_{\text {basa }} \times 10^{5}}{\mathrm{~V}_{\text {sampel }}(\mathrm{mg})}
$$

\subsection{Penentuan Kandungan Gugus -OH Fenolik}

Kandungan gugus fenolik dihitung dari selisih total keasaman dengan kandungan gugus karboksilat, seperti pada persamaan berikut ini [12]:

$$
\text { Kandungan gugus fenolik }\left(\mathrm{cmol} \mathrm{kg}^{-1}\right)=\mathrm{TA}\left(\mathrm{cmol} \mathrm{kg}^{-1}\right)-\mathrm{GK}\left(\mathrm{cmol} \mathrm{kg}^{-1}\right)
$$

\section{Hasil dan Pembahasan}

Sampel yang digunakan dalam penelitian ini adalah pupuk kotoran sapi. Pupuk kotoran sapi berasal dari kotoran sapi yang telah melalui proses pengomposan. Hipotesis penelitian ini adalah terdapat kandungan asam humat pada pupuk kotoran sapi. Hipotesis ini didasarkan pada konsep pembentukan senyawa humat yang terjadi melalui proses humifikasi yang melibatkan mikroorganisme. Secara umum senyawa humat berasal dari proses biosintesis polisakarida dan senyawa amino dengan melibatkan serangkaian proses oksidasi, demetilasi dan kondensasi dengan senyawa nitrogen [11]. Pengomposan merupakan pemodelan sederhana dari proses humifikasi dengan variabel kondisi yang lebih terukur. Komposisi asam humat yang diperoleh dari proses pengomposan tidak berbeda signifikan dengan komposisi asam humat yang diperoleh dari proses humifikasi [13].

Asam humat diekstrak dari pupuk kotoran sapi berdasarkan perbedaan kelarutannya dalam asam dan basa untuk memisahkannya dari senyawa humat yang lain (asam fulvat dan humin). Pupuk kotoran sapi dicampurkan dengan larutan basa kuat yaitu KOH. Larutan basa kuat lebih baik dalam mengekstraksi asam humat daripada larutan asam lemah maupun [12]. Pernyataan ini dikuatkan dengan hasil penelitian lain yang membuktikan bahwa perolehan asam humat dari proses ekstraksi dengan larutan $\mathrm{KOH}$ menghasilkan rendemen sebesar $46 \%$ lebih banyak daripada perolehan asam humat dari proses ekstraksi dengan larutan $\mathrm{NaOH}$ pada konsentrasi yang sama [14]. Alkaline extraction (ekstraksi dengan basa) bertujuan untuk mengekstrak karbon total dan karbohidrat dari kotoran sapi [15]. 
Pencampuran asam humat dengan larutan $\mathrm{KOH}$ bertujuan melarutkan asam humat dan memisahkannya dari humin. Filtrat yang mengandung campuran asam humat dan asam fulvat kemudian diperlakukan dengan larutan asam yang bertujuan untuk memisahkan asam humat dengan asam fulvat, karena asam humat tidak larut dalam asam. Endapan yang terbentuk dari proses ini disebut sebagai asam humat.

Perlakuan dengan larutan asam (larutan $\mathrm{HCl}$ ) akan menyisakan kandungan ion $\mathrm{Cl}$, sehingga keberadaan ion ini harus dihilangkan dengan pencucian berulang dengan mengalirkan air demineral. Pengujian keberadaan ion $\mathrm{Cl}^{-}$dilakukan dengan cara menambahkan larutan $\mathrm{AgNO}_{3}$ ke dalam air yang telah dialirkan ke asam humat. Asam humat dikatakan bebas ion $\mathrm{Cl}^{-}$apabila tidak terbentuk endapan putih setelah ditambahkan $\mathrm{AgNO}_{3}$ ke dalam wadah, berdasarkan persamaan reaksi sebagai berikut:

$$
\mathrm{AgNO}_{3}+\mathrm{HCl} \rightarrow \mathrm{AgCl} \downarrow \text { (endapan putih) }+\mathrm{HNO}_{3}
$$

Pengaruh variasi konsentrasi larutan $\mathrm{KOH}$ yang digunakan terhadap perolehan asam humat dapat dilihat pada Gambar 1. Berdasarkan Gambar 1, perlakuan ekstraksi asam humat dengan larutan KOH dengan konsentrasi 0,050 M hingga 0,0250 M sebanding dengan peningkatan perolehan asam humat. Perlakuan ekstraksi asam humat dengan konsentrasi larutan $\mathrm{KOH} \mathrm{0,250}$ M menunjukkan perolehan asam humat terbanyak.

Perolehan asam humat dengan ekstraksi dengan konsentrasi larutan $\mathrm{KOH}$ lebih besar dari 0,25 M yaitu pada konsentrasi 0,5 M menunjukkan terjadinya penurunan perolehan asam humat. Menurut Apabila konsentrasi $\mathrm{KOH}$ yang tinggi menyebabkan meningkatnya peluang rusaknya ikatan antara asam fulvat dengan asam humat, seperti ikatan $-\mathrm{H}$ atau ikatan tipe-ester [16]. Keadaan tersebut akan mengubah rasio asam humat dan asam fulvat, akibatnya perolehan filtrat hasil perlakuan dengan larutan $\mathrm{KOH} \mathrm{0,5} \mathrm{M}$ lebih sedikit dari perolehan filtrat hasil perlakuan dengan larutan $\mathrm{KOH} \mathrm{0,25} \mathrm{M.} \mathrm{Filtrat} \mathrm{mengandung} \mathrm{asam} \mathrm{humat} \mathrm{yang} \mathrm{larut} \mathrm{dalam}$ larutan basa.

Pengaruh waktu pengocokan pupuk komps kotoran sapi dengan larutan $\mathrm{KOH}$ 0,25 M terhadap perolehan asam humat dapat dilihat pada Gambar 2. Gambar 2 menunjukkan waktu pengocokan optimum adalah 2 jam, dimana diperoleh massa asam humat paling besar. Hasil uji Anova menunjukkan bahwa perolehan asam humat dengan waktu pengocokan 1 jam dan 2 jam memberikan perbedaan hasil perolehan asam humat yang signifikan. Penambahan waktu pengocokan melebihi 2 jam tidak signifikan terhadap perolehan massa asam humat.

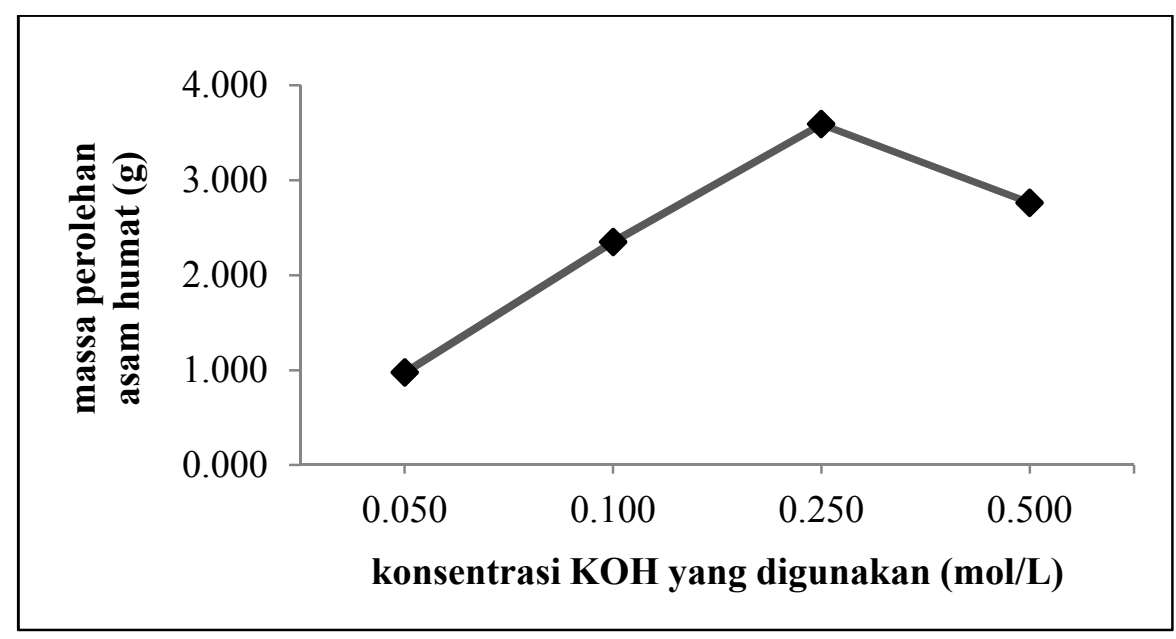

Gambar 1. Pengaruh konsentrasi KOH yang digunakan dengan perolehan asam humat dari pupuk kotoran sapi 


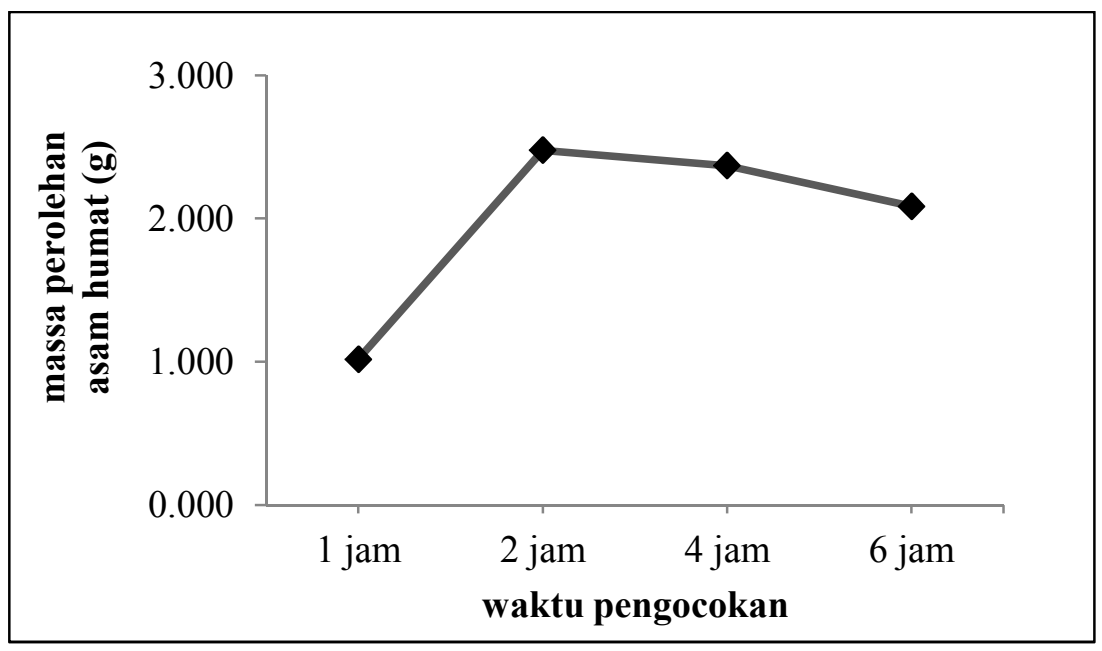

Gambar 2. Pengaruh waktu pengocokan terhadap perolehan asam humat dari pupuk kotoran sapi

Ekstraksi pupuk kotoran sapi dengan larutan $\mathrm{KOH} \mathrm{0,250} \mathrm{M} \mathrm{dengan} \mathrm{waktu} \mathrm{pengocokan} 2$ jam menghasilkan asam humat dengan perolehan terbanyak 4,486\%. Asam humat yang diperoleh kemudian dikarakterisasi serapan gugus fungsinya dengan spektrometri FTIR (Gambar 3). Karakterisasi serapan gugus fungsi asam humat hasil ekstraksi dari pupuk kotoran sapi dibandingkan dengan serapan gugus fungsi asam humat standar dan serapan gugus fungsi asam humat menurut Stevenson [12]. Perbandingan bilangan gelombang yang muncul pada asam humat hasil ekstraksi dari pupuk kotoran sapi dengan asam humat standar dan asam humat menurut Stevenson disajikan pada Tabel 1.

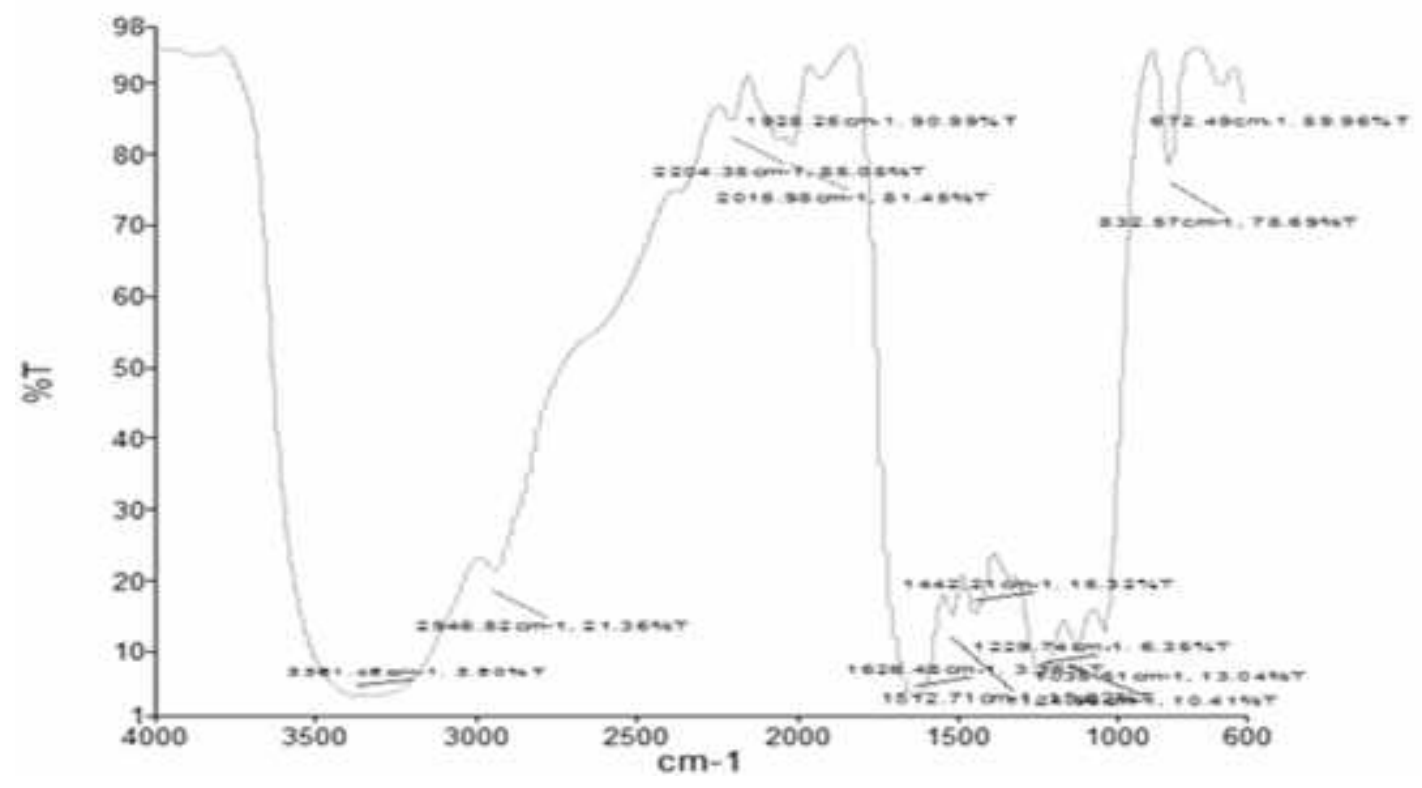

Gambar 3. Spektrum FTIR asam humat hasil ekstraksi dari pupuk kotoran sapi

Berdasarkan interpretasi spektra FTIR, asam humat hasil ekstraksi dari pupuk kotoran sapi mengandung gugus fungsional hidroksil $(-\mathrm{OH})$ dan karboksilat $(-\mathrm{COOH})$. Indikasi keberadaan gugus $-\mathrm{OH}$ ditandai dengan munculnya vibrasi perubahan (deformation) $-\mathrm{OH}$ dari $-\mathrm{COOH}$ dan regang-C-O yang teridentifikasi pada bilangan gelombang $1229,74 \mathrm{~cm}^{-1}$. Keberadaan gugus $\mathrm{COOH}$ ditunjukkan dengan munculnya karakteristik serapan gugus fungsi $-\mathrm{OH}$ dari $-\mathrm{COOH}$ pada bilangan gelombang $3361,46 \mathrm{~cm}^{-1}$, meskipun serapan yang menunjukkan adanya gugus karbonil $(-\mathrm{C}=0-)$ yang umumnya muncul pada bilangan gelombang $1725-1720 \mathrm{~cm}^{-1}$ tidak muncul 
dalam spektra asam humat hasil ekstraksi, demikian juga pada asam humat standar. Tidak munculnya serapan gugus $-\mathrm{C}=0$ pada bilangan gelombang $1700 \mathrm{~cm}^{-1}$, yang secara khas menunjukkan keberadaan - $\mathrm{COOH}$, dikarenakan adanya peluang terjadinya ikatan antara gugus $\mathrm{COOH}$ dengan logam yang dimungkinkan terkandung dalam pupuk kotoran sapi [18]. Kandungan logam dari kotoran sapi dapat berasal dari unsur hara makro seperti kalium (K), magnesium (Mg), kalsium (Ca), dan lain-lain.

Tabel 1. Bilangan Gelombang Asam Humat Standar, Asam Humat Hasil Ekstraksi dari Pupuk Kotoran Sapi dan Asam Humat Menurut Stevenson

\begin{tabular}{|c|c|c|c|}
\hline \multicolumn{3}{|c|}{ Bilangan gelombang $\left(\mathrm{cm}^{-1}\right)$} & \multirow[b]{2}{*}{ Gugus Terkait } \\
\hline $\begin{array}{l}\text { Asam Humat } \\
\text { Standar [17] }\end{array}$ & $\begin{array}{l}\text { Asam Humat } \\
\text { Hasil Ekstraksi } \\
\text { dari Pupuk } \\
\text { Kotoran Sapi }\end{array}$ & $\begin{array}{c}\text { Asam Humat } \\
\text { menurut } \\
\text { Stevenson } \\
\text { [12] }\end{array}$ & \\
\hline 3425,58 & 3361,46 & $3400-3300$ & regang $-\mathrm{OH}$ atau $\mathrm{N}-\mathrm{H}$ \\
\hline 2924,09 & 2946,52 & $2940-2900$ & $\begin{array}{l}\text { regang simetri dan asimetri } \mathrm{C}-\mathrm{H} \text { alifatik dari } \\
\mathrm{CH}_{2} \text { atau }-\mathrm{CH}_{3}\end{array}$ \\
\hline- & - & $1725-1720$ & regang $\mathrm{C}=0$ dari gugus $-\mathrm{COOH}$ atau keton \\
\hline - & - & $1660-1630$ & $\begin{array}{l}\text { regang } \mathrm{C}=0 \text { dari gugus amida, }-\mathrm{C}=0 \text { dari } \\
\text { kuinon dan atau }-\mathrm{C}=0 \text { keton }\end{array}$ \\
\hline- & 1626,70 & $1620-1600$ & $\begin{array}{l}\mathrm{C}=\mathrm{C} \text { aromatik, } \mathrm{H} \text { terkonjugasi dari gugus } \\
\mathrm{C}=\mathrm{O} \text { dari keton dan atau karboksilat } \\
\text { regang simetrik } \mathrm{COO}-\text {, deformation } \mathrm{N}-\mathrm{H} \text { dan }\end{array}$ \\
\hline 1573,91 & 1521,71 & $1590-1517$ & $\begin{array}{l}\text { vibrasi ulur }-\mathrm{C}=\mathrm{N} \text { dari amida ikatan } \\
\text { rangkap } 2\end{array}$ \\
\hline- & 1442,24 & $1460-1450$ & $\begin{array}{l}\mathrm{C}-\mathrm{H} \text { alifatik } \\
\text { deformation }-\mathrm{O}-\mathrm{H} \text {, regang } \mathrm{C}-\mathrm{O} \text { dari }\end{array}$ \\
\hline 1388,75 & - & $1400-1390$ & $\begin{array}{l}\mathrm{OH} \text { fenolik, deformation } \mathrm{C}-\mathrm{H} \text { dari }-\mathrm{CH}_{2} \text { dan } \\
\mathrm{CH}_{3}\end{array}$ \\
\hline- & 1229,74 & $1280-1200$ & Regang $\mathrm{C}-\mathrm{O}$, deformation $-\mathrm{OH}$, ulur $-\mathrm{CH}_{3}$ \\
\hline
\end{tabular}

Serapan pada bilangan gelombang 2946,52 $\mathrm{cm}^{-1}$ menunjukkan vibrasi C-H alifatik dari $\mathrm{CH}_{2}$ atau $-\mathrm{CH}_{3}$. Serapan khas dari asam humat juga muncul pada bilangan gelombang $1626,70 \mathrm{~cm}^{-1}$. Keberadaan pita serapan dari regang simetrik COO- atau perubahan vibrasi N-H dan vibrasi ulur $-\mathrm{C}=\mathrm{N}$ dari amida ikatan rangkap 2 terindikasi pada bilangan gelombang $1521,71 \mathrm{~cm}^{-1}$. Serapan ini mengindikasikan gugus $\mathrm{C}=\mathrm{C}$ dari cincin aromatik dan atau $\mathrm{H}$ terkonjugasi $\mathrm{C}=0$ dari gugus karbonil (karboksilat dan keton). Serapan pada bilangan gelombang $1230 \mathrm{~cm}^{-1}$ menunjukkan perubahan vibrasi $\mathrm{C}=\mathrm{O}$ dari gugus karboksilat khususnya dari $-\mathrm{COOH}$.

Secara teoritis, keberadaan gugus fungsi $-\mathrm{COOH}$ dan $-\mathrm{OH}$ dari enolat/fenolat pada asam humat menyebabkan asam humat bersifat asam, karena pelepasan ion $\mathrm{H}^{+}$dari gugus-gugus tersebut. Total keasamaan, kandungan $-\mathrm{COOH}$ dan $-\mathrm{OH}$ fenolat asam humat hasil ekstraksi dari pupuk kotoran sapi dianalisis secara kuantitatif melalui serangkaian metode. Hasil uji kandungan gugus fungsional asam humat disajikan pada Tabel 2. 
Tabel 2. Kandungan Gugus Fungsi Asam Humat Hasil Ekstraksi Pupuk Kotoran Sapi

\begin{tabular}{lcc}
\hline \multirow{2}{*}{ Gugus fungsi } & \multicolumn{2}{c}{ Kadar gugus dalam asam humat $\left(\mathrm{cmol}^{\mathrm{k}} \mathrm{kg}^{-1}\right)$} \\
\cline { 2 - 3 } & Asam humat menurut Schnitzer [19] & Asam humat hasil ekstraksi \\
\hline Total keasaman & $560-890$ & 500 \\
Gugus karboksilat & $150-570$ & 250 \\
Gugus fenolik & $270-350$ & 250 \\
\hline
\end{tabular}

Penetapan kandungan total keasaman didasarkan pada pertukaran kation $\mathrm{H}^{+}$dari asam humat dengan kation $\mathrm{Ba}^{2+}$ dari $\mathrm{Ba}(\mathrm{OH})_{2}$. Prinsip reaksi juga dapat dikatakan sebagai reaksi penetralan asam-basa yang menghasilkan garam dan air. Asam humat (ditulis dengan lambang $\mathrm{RH}$, dimana $\mathrm{R}$ adalah makromolekul asam humat dan $\mathrm{H}$ adalah proton dari gugus $-\mathrm{COOH}$ dan $\mathrm{OH}$ yang akan ditransfer/dilepaskan) akan bereaksi dengan larutan $\mathrm{Ba}(\mathrm{OH})_{2}$ berlebih yang bersifat basa, sehingga ion $\mathrm{H}^{+}$dari asam humat $(\mathrm{RH})$ dilepaskan. Ion $\mathrm{R}^{-}$berikatan dengan ion $\mathrm{Ba}^{2+}$ dari larurtan $\mathrm{Ba}(\mathrm{OH})_{2}$ membentuk garam $\mathrm{R}_{2} \mathrm{Ba}$. Ion $\mathrm{H}^{+}$dari $\mathrm{RH}$ bergabung dengan ion $\mathrm{OH}^{-}$ dari larutan $\mathrm{Ba}(\mathrm{OH})_{2}$ membentuk $\mathrm{H}_{2} \mathrm{O}$. Ion $\mathrm{OH}$ - yang berlebih dari $\mathrm{Ba}(\mathrm{OH})_{2}$ dititrasi dengan dengan larutan $\mathrm{HCl}$. Banyaknya volume larutan $\mathrm{HCl}$ yang akan digunakan untuk titrasi akan sebanding dengan banyaknya $\mathrm{Ba}(\mathrm{OH})_{2}$ sisa, sehingga dapat ditentukan berapa banyak konsentrasi ion $\mathrm{OH}^{-}$dari $\mathrm{Ba}(\mathrm{OH})_{2}$ yang digunakan untuk menetralkan ion $\mathrm{H}^{+}$yang dilepaskan dari RH. Persamaan reaksi yang terjadi dituliskan sebagai berikut:

$$
\begin{aligned}
& 2 \mathrm{RH}+\mathrm{Ba}(\mathrm{OH})_{2} \text { (berlebih) } \rightarrow \mathrm{R}_{2} \mathrm{Ba}+2 \mathrm{H}_{2} \mathrm{O} \\
& \mathrm{Ba}(\mathrm{OH})_{2} \text { (sisa) }+2 \mathrm{HCl} \rightarrow \mathrm{BaCl}_{2}+2 \mathrm{H}_{2} \mathrm{O}
\end{aligned}
$$

Penentuan gugus karboksilat dilakukan dengan menggunakan metode Ca-asetat. Prinsip dari metode Ca-asetat adalah prinsip pertukaran kation $\mathrm{H}^{+}$dari asam humat (dilambangan dengan R-COOH) dengan kation $\mathrm{Ca}^{2+}$ dari larutan $\mathrm{Ca}\left(\mathrm{CH}_{3} \mathrm{COO}\right)_{2}$ berlebih. Banyaknya $\mathrm{Ca}^{2+}$ yang dipertukarkan sebanding dengan ion $\mathrm{H}^{+}$yang dilepaskan dari asam humat. Larutan $\mathrm{Ca}\left(\mathrm{CH}_{3} \mathrm{COO}\right)_{2}$ sisa kemudian dititrasi dengan dengan larutan $\mathrm{NaOH}$. Persamaan reaksi yang terjadi adalah sebagai berikut:

$$
\begin{gathered}
2 \mathrm{R}-\mathrm{COOH}+\mathrm{Ba}\left(\mathrm{CH}_{3} \mathrm{COO}\right)_{2} \rightarrow \mathrm{Ba}(\mathrm{R}-\mathrm{COO})_{2}+2 \mathrm{CH}_{3} \mathrm{COOH} \\
\mathrm{CH}_{3} \mathrm{COOH}+\mathrm{NaOH} \rightarrow \mathrm{CH}_{3} \mathrm{COONa}+\mathrm{H}_{2} \mathrm{O}
\end{gathered}
$$

Penentuan kandungan gugus - $\mathrm{OH}$ fenolik atau asam - $\mathrm{OH}$ diperoleh dari merupakan selisih antara total keasaman dan kandungan gugus karboksilat. Hanya - $\mathrm{OH}$ yang dapat beraksi dengan $\mathrm{Ba}(\mathrm{OH})_{2}$ yang dapat ditentukan dengan menggunakan pendekatan perhitungan ini.

Berdasarkan perhitungan, asam humat hasil ektraksi pupuk kotoran sapi mengandung total keasaman dan kandungan karboksilat yang memenuhi rentang nilai yang diberikan oleh Schnitzer [19]. Namun nilai gugus $-\mathrm{OH}$ fenolik tidak memenuhi rentang nilai yang diberikan oleh Schnitzer [19]. Hal ini dapat disebabkan karena ada ion $\mathrm{H}^{+}$dari asam humat dari yang belum atau tidak bereaksi dengan $\mathrm{Ba}(\mathrm{OH})_{2}$ dalam penentuan total keasamaan, sehingga nilai total keasaman yang terhitung lebih kecil dari kandungan total keasaman yang sebenarnya. 


\section{Kesimpulan}

Berdasarkan hasil penelitian dapat disimpulkan bahwa asam humat berhasil diekstraksi dari pupuk kotoran sapi larutan KOH 0,250 sebagai larutan pengesktrak dan waktu pengocokan selama 2 jam, dengan perolehan hasil sebesar 4,486\%. Spektrum FTIR menunjukkan serapan khas untuk asam humat yaitu pada bilangan gelombang untuk gugus-gugus $-\mathrm{OH}$ dan regang $\mathrm{N}-\mathrm{H}$ (3361, $\left.46 \mathrm{~cm}^{-1}\right)$; $\mathrm{C}-\mathrm{H}$ alifatik untuk $\mathrm{CH}_{2}, \mathrm{CH}_{3}\left(2946,52 \mathrm{~cm}^{-1}\right.$ dan $\left.1442,24 \mathrm{~cm}^{-1}\right) ; \mathrm{C}=\mathrm{C}$ aromatik $\left(1626,48 \mathrm{~cm}^{-1}\right)$; regang simetrik COO- $\left(1521,71 \mathrm{~cm}^{-1}\right)$; C-O dari $-\mathrm{COOH}\left(1229,74 \mathrm{~cm}^{-1}\right)$. Asam

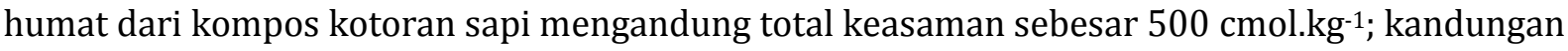
gugus karboksilat sebesar $250 \mathrm{cmol}^{\mathrm{kg}}{ }^{-1}$ dan kandungan -OH fenolik sebesar $250 \mathrm{cmol} . \mathrm{kg}^{-1}$.

\section{Referensi}

[1] Wershaw R. L. Evaluation of Conceptual Models of Natural Organic Matter (Humus) From a Consideration of the Chemical and Biochemical Processes of Humification. Scientific Investigations Report 2004-5121U.S. Department of the Interior and U.S. Geological Survey Denver; 2004.

[2] Bashir, M., Qadri, R. W. K., Khan, I., Zain, M., Rasool, A., \& Ashraf, U. Humic acid application improves the growth, floret and bulb indices of Gladiolus (Gladiolus grandiflorus L.). Pakistan Journal of Science. 2016; 68 (2):121-127.

[3] Xue, X., Xue, Z., Song, Z., Zhang, F., Wang, Z., \& Han, Y. Effect of combined application of humic acid and urea on the wheat growth and yield. Asian Agricultural Research. 2016; 8 (9):67-70.

[4] Wang, X., Su, Y., Xu, X., \& Li, G. Effect of fulvic acid on growth and yield components of direct seeding rice, Agricultural Science \& Technology. 2013; 14 (7):966-972.

[5] Dai, M., Chen, Q., Hu, Z., Li, X., Zhang, J., Wang, J., \& Feng, H. Effects of humic acid and PASP compound fertilizer application on growth, quality and yield of Broccoli, Agricultural Science \& Technology. 2016; 17 (3):535-538.

[6] Zandonadi D. B., Santos M. P., Busato J. G., Peres L.E.P, Façanha, A.R. Plant physiology as affected by humified organic matter, Theor. Exp. Plant Physiol. 2013; 25 (1):12-25.

[7] Canellas LP,Spaccini R, Piccolo A, Dobbss LB, Façanha ALO, Santos GA, Olivares FL, and Façanha A.R. Relationships Between Chemical Characteristics and Root Growth Promotion of Humic Acids Isolated From Brazilian Oxisols, Soil Science. 2009; 174 (11):611-620.

[8] Wijaya H. and Suwardi. Peningkatan Produksi Tanaman Pangan dengan Bahan Aktif Asam Humat dengan Zeolit sebagai Pembawa, Jurnal IImu Pertanian Indonesia. 2013; 18 (2):79.

[9] Khaled H., and Fawy H.A. 2011. Effect of Different Levels of Humic Acids on the Nutrient Content, Plant Growth, and Soil Properties under Conditions of Salinity, Soil \& Water Res. 2011; 6 (1):21-29.

[10] Barot, N.S. and Bagla, H.K. Extraction of humic acid from biological matrix-dry cow dung powder. Journal Green Chemistry Letters and Review. 2009; 2 (4):217-221.

[11] Nagasawa, K., Wang, B., Nishiya, K., Ushijima, K., Zhu, Q., Fukushima, M., Ichijo, T. Effects of humic acids derived from lignite and cattle manure on antioxidant enzymatic activities of barley root, J Environ Sci Health B. 2016; 51 (2):81-89.

[12] Stevenson, F.J. 1994. Humus Chemistry: Genesis, Composition, Reaction. $2^{\text {nd }}$ ed. John Wiley \& Sons, Inc. New York.

[13] Monedero, M.A.S., Cegarra, J., Garcia, D. and Roig, A. Chemical and structural evolution of humic acids during organic waste composting, Biodegradation. 2002; 13:361-371.

[14] Fong, S.S., Lau S., Wong N.C., Janice A., Muhammad F., and Amira S, 2006, Characterization of the Coal Derived Humic Acids from Mukah Sarawak as Soil Conditioner, J. Braz Chem Soc. 2006; 17(2):582-587.

[15] Bellera, C., Abaalkheel, I., Rovira, P. and Alrefai, J. Obtaining commercial humic products from uncomposted manures: previous acid hydrolysis to enhance yields, Int J Recycl Org Waste Agricult. 2015; 4:219-231. 
[16] Asing J , N.C. Wong and S. Lau. Optimization Of Extraction Method And Characterization Of Humic Acid Derived From Coals and Composts. J. Trop. Agric. and Fd. Sc. 2009; 37 (2): 211-223.

[17] Astuti, P., Idiawati, N., dan Destiarti, L., 2015. Validasi Metode Pengukuran Kadar Asam Humat Hasil Ekstraksi Kalium Hidroksida dengan Spektrofotometri Ultraviolet, Jurnal Kimia Khatuslitiwa. 2015; 5 (2):69-77.

[18] Mohadi, R., Hidayati, N., Santosa, S.J. Narsito. 2008. Karakterisasi Asam Humat dari Gambut Indralaya, Ogan Ilir Sumatera Selatan, Jurnal Penelitian Sains. 11(1):411-420.

[19] Schnitzer, M. 1986. Pengikatan Bahan Humat Oleh Koloid Mineral Tanah, dalam buku Interaksi Mineral Tanah dengan Organik Alami dan Mikroba, 1997, Huang, P. M dan Schnitzer, M. (editor), Gadjah Mada University Press, Yogakarta, 119-155. 